\title{
DUATHLON TRAINING MODEL ADAPTED FOR FEMALE RATS: BLOOD GLUCOSE-LACTATE CORRELATIONS
}

\author{
MODELO DE TREINAMENTO DE DUATHLON ADAPTADO PARA RATAS:CORRELAÇÃO DE \\ GLICOSE-LACTATO NO SANGUE
}

Original Article

Artigo OrIGINAL

Artículo Original

Francisco Sérgio Lopes

Vasconcelos Filho'

(Physical Education Professional)

Mateus Bastos de Souza²

(Physiotherapy Student)

Jefferson Pacheco Amaral Fortes ${ }^{1,3}$

(Physiotherapist)

Karla Camila Lima de Souza'

(Physiotherapist)

Mayara Rangel Araújo Carneiro ${ }^{4}$

(Physiotherapist)

Francisco Fleury Uchoa

Santos-Júnior ${ }^{3,4}$

(Physiotherapist)

Vânia Marilande Ceccatto ${ }^{1}$

(Biologist)

1. Universidade Estadual do Ceará, Fortaleza, CE, Brazil.

2. Universidade Federal do Ceará,

Fortaleza, CE, Brazil.

3. Instituto Le Santé, Fortaleza,

CE, Brazil.

4. Centro Universitário Estácio do

Ceará, Fortaleza, CE, Brazil.

\section{Correspondence:}

Vânia Marilande Ceccatto,

Biochemistry and Gene Expression Laboratory, Instituto Superior de Ciências Biomédicas. Av. Dr. Silas Munguba, 1700, Campus do Itaperi. Fortaleza, CE, Brazil. 60714-903.

vania.ceccatto@uece.br

\begin{abstract}
Objective:To propose a duathlon model adapted for rats (associated swimming and running training) and compare it with the individual activities carried out separately, considering the glucose uptake and serum lactate production mechanism. Methods: Twenty-eight 90-day-old Wistar rats with a mean weight of 150-200 $\mathrm{g}$ were used. The animals were divided into four groups: control group, swimming group, running group, and swimming/running group. These animals were adapted to their respective training programs for three days and underwent the 4-week training protocol soon afterwards. Pre- and post-training blood lactate and blood glucose analyses were performed at the end of each week. Statistical difference was considered when the $p$ value was less than $0.01(p<0.01)$. Results: There was a decrease in glycemic levels and an increase in lactate levels in the swimming and swimming/running groups throughout the training period, which did not occur in the running group. Conclusion: The duathlon model adapted for rats proved satisfactory in terms of the production and stabilization of blood lactate levels. Level of evidence Il; Therapeutic Studies - Investigating the Results of Treatment.
\end{abstract}

Keywords: Running; Swimming; Lactate; Glucose.

\section{RESUMO}

Objetivo: Propor um modelo de duathlon adaptado para ratos (treinamento associado de natação e corrida) e compará-lo com as modalidades praticadas isoladamente, considerando o mecanismo de consumo de glicose e produção de lactato sérico. Métodos: Foram utilizados vinte e oito ratos Wistar, com 90 dias de vida e peso médio de 150-200 g. Os animais foram divididos em quatro grupos: grupo controle, grupo de natação, grupo de corrida e grupo de natação/corrida. Esses foram adaptados aos seus respectivos treinos durante três dias e, logo depois, foram submetidos ao protocolo de treinamento com duração de quatro semanas. No final de cada semana, foram realizadas análises de lactato e glicose sanguínea pré- e pós- treinamento. A diferença estatística foi considerada quando o valor pera inferior a 0,01 $(p<0,01)$. Resultados: Houve diminuição nos níveis de glicemia e aumento nos níveis de lactato nos grupos de natação e natação/corrida ao longo do período de treinamento, o que não ocorreu no grupo de corrida. Conclusão: Pode-se verificar que o modelo duathlon adaptado para ratos foi satisfatório em relação à produção e estabilização dos níveis sanguíneos de lactato. Nível de evidência ll; Estudos terapêuticos Investigação dos resultados de tratamento.

Descritores: Corrida; Natação; Lactato; Glicose.

\section{RESUMEN}

Objetivo: Proponer un modelo de duatlón adaptado para ratones (entrenamiento asociado de natación y carrera) y compararlo con las modalidades practicadas aisladamente, considerando el mecanismo de consumo de glucosay producción de lactato sérico. Métodos: Fueron utilizados veintiocho ratones Wistar, con 90 días de vida y peso promedio de 150-200 g. Los animales fueron divididos en cuatro grupos: grupo control, grupo de natación, grupo de carrera y grupo de natación/carrera. Esos fueron adaptados a sus respectivos entrenamientos durante tres días y, luego después, fueron sometidos al protocolo de entrenamiento con duración de cuatro semanas. Al final de cada semana, fueron realizados análisis de lactato y glucosa sanguínea prey post entrenamiento. La diferencia estadística fue considerada cuando el valor p era inferior a 0,01 ( $p<0,01)$. Resultados: Hubo disminución en los niveles de glucemia y aumento en los niveles de lactato en los grupos de natación y natación/carrera a lo largo del período de entrenamiento, lo que no ocurrió en el grupo de carrera. Conclusión: Se puede verificar que el modelo duatlón adaptado para ratones fue satisfactorio con relación a la producción y estabilización de los niveles sanguíneos de lactato. Nivel de evidencia ll; Estudios terapéuticos - Investigación de los resultados del tratamento.

Descriptores: Carrera; Natación; Lactato; Glucosa. 


\section{INTRODUCTION}

The duathlon, in its most common form, is characterized as a multi-sport activity composed of two modalities within the same competition (running and pedal). Presenting some variations within this perspective of two sports, one can cite the Aquathlon, which involves the modalities of running and swimming. According to the USA Triathlon National and the International Triathlon Union, the Aquathlon consists of three segments, the first being 2.5 kilometers of running, the second 1 kilometer of swimming and the third plus 2.5 kilometers of running'. Competitions involving these modalities require a high physical conditioning and high energy demand, due to the need to execute combinations of sports modalities within a single event ${ }^{2,3}$.

Keeping the rhythm of an exercise at high intensity for a long period of time implies a higher production and later accumulation of lactate and $\mathrm{H}^{+}$ ions in the bloodstream originated from anaerobic metabolism, one of the factors that can lead to muscle fatigue 4 . When the lactate production percentage is equal to its removal, either by oxidation or conversion to glucose in muscle and liver, the individual can maintain a steady exercise intensity, at this point it is called the maximal lactate steady state concentration ${ }^{1,5}$. Therefore the measurement of the threshold becomes important, since it is gold standard to define both the intensity of exercise and aerobic capacity ${ }^{5}$.

The main energy sources to maintain high intensity exercise comes from glycogen and plasma glucose $e^{6}$. However, in longer durations, they can be depleted, causing fatigue. In addition, plasma glucose is used to restore muscle glycogen levels?.

In view of the above, the present study aims to propose a Duathlon model adapted for rats (associated training of swimming and running) and to compare it with the modalities practiced in isolation, in the light of the verification of the mechanism of consumption of glucose and blood lactate production.

\section{MATERIALS AND METHODS}

It was used 28 female Wistar rats at 3 months of age, weighting from 150 to $200 \mathrm{~g}$. The animals were obtained at the Higher Institute of Biomedical Sciences of the State University of Ceará (UECE). The animals were kept in shared cages (4 animals/cage), light/dark cycle (12h / 12h), in a temperature controlled environment between $22^{\circ}$ and $25^{\circ} \mathrm{C}$ with food and water ad libitum. The animals were randomly divided into four groups $(n=7)$ : sedentary control (SC), swimming group (SG), running group ( $\mathrm{RG}$ ) and swimming-running group (SRG). All experiments were performed in accordance with the Ethics Committee for Animal Use of UECE, under the process no 7007456/2015.

\section{Adaptation and Training}

Before starting the training protocols, the animals went through an adjustment period, in which the RG and SG trained for three consecutive days (first two days - 3 minutes; third day - six minutes). The SRG followed the same adaptation period, in the first half was done swimming and in the second half, running (example: six minutes of training - 3 minutes of swimming and the other 3 minutes of running).

After proper adjustment to the training environment, the animals were submitted to their specific training protocols. The RG protocol (Table 1) consisted of four weeks of treadmill running, adapted to rodents (IMBRAMED $\left.{ }^{\circledR}\right)$, with a progression in time (Day 1 - 5 minutes; Day 2-10 minutes;
Day 3 - 15 minutes and maintaining this time until Saturday of the first week; Day 8 - 20 minutes, Day 9 - 25 minutes; Day 10 - 30 minutes maintained until the end of the four weeks experiment) and the speed of the treadmill (1st minute $-0.2 \mathrm{~km} / \mathrm{h}$, 2nd minute $-0.4 \mathrm{~km} / \mathrm{h}$, 3rd minute $-0.8 \mathrm{~km} / \mathrm{h}$, 4th minute $-1.0 \mathrm{~km} / \mathrm{h}$, 5th minute $-1,2 \mathrm{~km} / \mathrm{h}$ ) stabilizing at $1.2 \mathrm{~km} / \mathrm{h}$ during the course of the daily training time (Figure 1$)^{8}$.

SG animals (Table 1) were submitted to swimming training for 4 weeks in an adapted tank (120 cm in diameter and $60 \mathrm{~cm}$ in height), supporting an overload of $8 \%$ of the body weight attached to the tail of the animal and with an increase in training time similar to previously described $(\mathrm{RG})^{9}$.

The adapted Duathlon training model consisted of swimming with an overload of $8 \%$ of the body weight of the animal attached to the tail, followed by running for 4 weeks, with progression in training time similar to that already mentioned. The SRG training was constituted through the association of swimming and running, respectively and followed the same line of the example cited for the adaptation of this same group (Table 2). It is noteworthy that SG and SRG animals were weighed weekly to adjust the overload used in the aquatic training. SC remained sedentary throughout the experiment period, being submitted to only one exercise session per week, equivalent to the time of the adaptation period.

\section{Lactate analysis}

Before and after the last weekly training session of each modality of training, blood was collected ( $25 \mathrm{uL}$ ) from the animal's tail using a capillary calibrated with EDTA. Immediately after collection, the blood sample was transferred to an eppendorf tube containing $50 \mathrm{uL}$ of sodium fluoride. Subsequently, the samples were kept in the refrigerator until further analysis using a lactimeter (YSI 2300 Stat Analyzer, Yellow Springs Instruments, Yellow Springs, OH, EUA). Data were expressed in millimoles per liter of blood lactate $(\mathrm{mmol} / \mathrm{L})$.

\section{Blood Glucose Analysis}

Blood glucose levels were analyzed before and after the last session of the weekly training through a monitoring system (Accu-Check Active ${ }^{\circ}$. A small amount of blood from the distal portion of the rat tail were collected. Data expressed in milligrams of glucose per deciliter of blood $(\mathrm{mg} / \mathrm{dL})$.

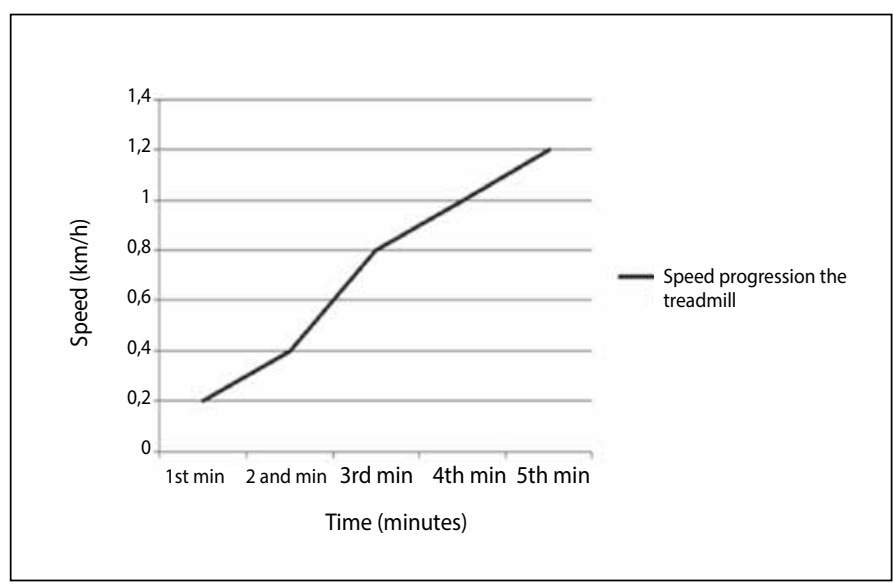

Figure 1. Speed progression on the treadmill.

Table 1. Training protocol for swimming and running groups.

\begin{tabular}{|c|c|c|c|c|c|c|c|}
\hline Day & Monday & Tuesday & Wednesday & Thursday & Friday & Saturday & Sunday \\
\hline Week & $\begin{array}{l}\text { Duration } \\
\text { (min) }\end{array}$ & $\begin{array}{c}\text { Duration } \\
\text { (min) }\end{array}$ & $\begin{array}{c}\text { Duration } \\
\text { (min) }\end{array}$ & $\begin{array}{l}\text { Duration } \\
\text { (min) }\end{array}$ & $\begin{array}{c}\text { Duration } \\
\text { (min) }\end{array}$ & $\begin{array}{c}\text { Duration } \\
\text { (min) }\end{array}$ & Rest \\
\hline $1 \mathrm{st}$ & $5 \mathrm{~min}$ & $10 \mathrm{~min}$ & $15 \min$ & $15 \mathrm{~min}$ & $15 \mathrm{~min}$ & $15 \mathrm{~min}$ & Rest \\
\hline 2nd & $20 \mathrm{~min}$ & $25 \mathrm{~min}$ & $30 \mathrm{~min}$ & $30 \mathrm{~min}$ & $30 \mathrm{~min}$ & $30 \mathrm{~min}$ & Rest \\
\hline $3 r d$ & $30 \mathrm{~min}$ & $30 \mathrm{~min}$ & $30 \mathrm{~min}$ & $30 \mathrm{~min}$ & $30 \mathrm{~min}$ & $30 \mathrm{~min}$ & Rest \\
\hline 4th & $30 \mathrm{~min}$ & $30 \mathrm{~min}$ & $30 \mathrm{~min}$ & $30 \mathrm{~min}$ & $30 \mathrm{~min}$ & $30 \mathrm{~min}$ & Rest \\
\hline
\end{tabular}




\section{Statistical analysis}

The data were submitted to the Kolmogorov-Smirnov Test to check its standardization, and then directed for further analysis. Data were expressed as mean \pm standard error of the mean. Regarding intragroup comparisons, pre-training and post-training, we used the Student's T Test for paired data and parametric Wilcoxon Test for nonparametric paired results. For intergroup analysis it was used the ANOVA two-way test followed by post hoc Bonferroni. In addition, the correlation was verified through Spearman test, between the change in blood glucose levels and pre and post-workout lactate $(\Delta)$. Statistical difference was considered when the $p$ value was less than $0.01(p<0.01)$.

\section{RESULTS}

Table 3 presents the data about glucose and lactate pre-workout and post-workout checked in the last training session of each week (test 1, 2, 3 and 4). It was possible to observe that the training generated significant modifications in almost all the tests, except for the running group that obtained few changes $(p<0.01)$.

However, the swimming group and swimming/running group showed a marked decrease in post-workout blood glucose at all stages of training (Figure $2 \mathrm{~A}$ and Table 1). This decrease was followed by an increase in blood lactate concentration after the training session (Figure 2B and Table 1).

According to the analysis of post-training and pre-training variation $(\Delta)$, it was observed that the sprint training generated a small variation in both plasma glucose and lactate, showing a slight increase of glycemia and low production of post training lactate when compared to swimming and swimming/running group throughout the training ( $p$ $<0.01$ ) (Figure 2A e 2B).

In addition, it was found a moderate inverse linear correlation ( $p$ $<0.0001$ ) between the glucose and lactate at baseline training (test 1) and strong in the other tests ( 2,3 and 4$)$, showing that during intense exercise, increased lactate concentration is followed by decrease of post-training glycemia (Figure 3).

\section{DISCUSSION}

In the present study, it was found that the Duathlon training model adapted for female rats, led to decreased post-workout blood glucose and increased post-workout lactate throughout the training period. This effect was also verified in the swimming group, differently from the running group that obtained few variations. In addition, it was possible to observe that the increase in serum lactate concentrations was accompanied by a decrease in blood glucose.

Glucose, both at rest and during exercise, especially when it is high-intensity, is the main source of energy used by the metabolism ${ }^{10}$. When blood glucose stores are reduced to critical levels, fatigue is triggered, making it difficult to provide energy and consequently maintaining high physical performance ${ }^{11}$

Blood glucose decrease presented in swimming and swimming/ running group corroborate with the findings of Chang et al. ${ }^{5}$, who noted that an acute session of intense training, such as exhausting treadmill, was able to reduce the glycemic index in healthy rats as well as chronic training ${ }^{12}$. This is probably due to the use of glucose as an energy source mediated by insulin ${ }^{5}$, and glucose transporter 4 protein $(G L U T 4)^{13}$. The exercise mediates the translocation of the glucose transporter 4 protein (GLUT4) to the cell surface thus favoring the synthesis of glycogen by increasing membrane permeability to glucose and decreasing its concentration in blood stream ${ }^{13}$. However, this mechanism seems to be more related to the training of moderate to high intensity, since the blood glucose concentrations in swimming and swimming/running group were significantly lower compared to the running group. Therefore, it may be suggested that the intensity of these groups is sufficient to deplete

Table 2. Swimming-running group training protocol.

\begin{tabular}{|c|c|c|c|c|c|c|c|}
\hline Day & Monday & Tuesday & Wednesday & Thursday & Friday & Saturday & Sunday \\
\hline Week & $\begin{array}{l}\text { Duration (min) } \\
S^{*} / R^{* *}\end{array}$ & $\begin{array}{l}\text { Duration (min) } \\
\text { S/R }\end{array}$ & $\begin{array}{l}\text { Duration (min) } \\
\text { S/R }\end{array}$ & $\begin{array}{l}\text { Duration (min) } \\
\text { S/R }\end{array}$ & $\begin{array}{c}\text { Duration (min) } \\
\text { S/R }\end{array}$ & $\begin{array}{l}\text { Duration (min) } \\
\text { S/R }\end{array}$ & Rest \\
\hline 1 st & $\begin{array}{c}2 \mathrm{~m} 30 \mathrm{~s}-\mathrm{S} / 2 \mathrm{~m} 30 \mathrm{~s}-\mathrm{R} \\
(5 \mathrm{~min})\end{array}$ & $5 m-S / 5 m-R(10 m i n)$ & $\begin{array}{c}7 \mathrm{~m} 30 \mathrm{~s}-\mathrm{S} / 7 \mathrm{~m} 30 \mathrm{~s} \\
-\mathrm{R}(15 \mathrm{~min})\end{array}$ & $\begin{array}{c}7 \mathrm{~m} 30 \mathrm{~s}-\mathrm{s} / 7 \mathrm{~m} 30 \mathrm{~s} \\
-\mathrm{R}(15 \mathrm{~min})\end{array}$ & $\begin{array}{c}7 \mathrm{~m} 30 \mathrm{~s}-\mathrm{S} / 7 \mathrm{~m} 30 \mathrm{~s} \\
-\mathrm{R}(15 \mathrm{~min})\end{array}$ & $\begin{array}{c}7 \mathrm{~m} 30 \mathrm{~s}-\mathrm{S} / 7 \mathrm{~m} 30 \mathrm{~s} \\
-\mathrm{R}(15 \mathrm{~min})\end{array}$ & Rest \\
\hline 2nd & $\begin{array}{c}10 m-S / 10 m \\
-R(20 m i n)\end{array}$ & $\begin{array}{c}12 \mathrm{~m} 30 \mathrm{~s}-\mathrm{S} / 12 \mathrm{~m} 30 \mathrm{~s} \\
-\mathrm{R}(25 \mathrm{~min})\end{array}$ & $\begin{array}{l}15 m-S / 15 m \\
-R(30 \mathrm{~min})\end{array}$ & $\begin{array}{l}15 m-S / 15 m \\
-R(30 m i n)\end{array}$ & $\begin{array}{l}15 m-S / 15 m \\
-R(30 \mathrm{~min}) \\
\end{array}$ & $\begin{array}{l}15 m-S / 15 m \\
-R(30 m i n)\end{array}$ & Rest \\
\hline $3 r d$ & $\begin{array}{c}15 m-S / 15 m \\
-R(30 m i n) \\
\end{array}$ & $\begin{array}{c}15 m-S / 15 m \\
-R(30 m i n) \\
\end{array}$ & $\begin{array}{c}15 m-S / 15 m \\
-R(30 \mathrm{~min}) \\
\end{array}$ & $\begin{array}{c}15 m-S / 15 m \\
-R(30 m i n) \\
\end{array}$ & $\begin{array}{c}15 m-S / 15 m \\
-R(30 \mathrm{~min}) \\
\end{array}$ & $\begin{array}{c}15 m-S / 15 m \\
-R(30 \mathrm{~min}) \\
\end{array}$ & Rest \\
\hline 4th & $\begin{array}{l}15 m-S / 15 m \\
-R(30 \mathrm{~min})\end{array}$ & $\begin{array}{l}15 m-S / 15 m \\
-R(30 m i n)\end{array}$ & $\begin{array}{l}15 m-S / 15 m \\
-R(30 m i n)\end{array}$ & $\begin{array}{l}15 m-S / 15 m \\
-R(30 \mathrm{~min})\end{array}$ & $\begin{array}{l}15 m-S / 15 m \\
-R(30 m i n)\end{array}$ & $\begin{array}{l}15 m-S / 15 m \\
-R(30 m i n)\end{array}$ & Rest \\
\hline
\end{tabular}

*Swimming; **Running.

Table 3. Analysis of pre and post training blood glucose and lactate during the four weeks of Duathlon training.

\begin{tabular}{|c|c|c|c|c|c|c|c|c|}
\hline \multirow[t]{2}{*}{ Groups } & \multicolumn{2}{|c|}{ Control Group } & \multicolumn{2}{|c|}{ Running Group } & \multicolumn{2}{|c|}{ Swimming Group } & \multicolumn{2}{|c|}{ Swimming/Running } \\
\hline & Pre & Post & Pre & Post & Pre & Post & Pre & Post \\
\hline \multicolumn{9}{|c|}{ Blood Glucose } \\
\hline Week 1 & $97.28 \pm 4.69$ & $70.85 \pm 5.84^{*}$ & $99.42 \pm 1.43$ & $90.57 \pm 2.81$ & $109.28 \pm 3.23$ & $46.65 \pm 1.76^{* b}$ & $110.4 \pm 19.54$ & $51.8 \pm 10.26 *, b$ \\
\hline Week 2 & $98.71 \pm 4.89$ & $63.14 \pm 7.42^{*}$ & $91.83 \pm 0.75$ & $101.82 \pm 1.13^{\mathrm{a}}$ & $92.15 \pm 1.19$ & $33.33 \pm 1.22^{* b}$ & $109.57 \pm 7.25$ & $66.28 \pm 14.58 * 8^{*}, \mathrm{c}$ \\
\hline Week 3 & $103.71 \pm 1.76$ & $89.28 \pm 9.22$ & $107.57 \pm 1.33$ & $116.14 \pm 1.96$ & $107.82 \pm 3.75$ & $46.33 \pm 1.3^{*, a, b}$ & $90.71 \pm 8$ & $52 \pm 9.39 *, a, b$ \\
\hline Week 4 & $106 \pm 1.04$ & $84 \pm 2.57^{*}$ & $91.71 \pm 1.09$ & $93.85 \pm 1.47$ & $97.82 \pm 0.81$ & $37.83 \pm 0.9^{*, a, b}$ & $113.57 \pm 5.58$ & $42.85 \pm 6.58^{*}, a, b$ \\
\hline \multicolumn{9}{|c|}{ Blood Lactate } \\
\hline Week 1 & $1.47 \pm 0.08$ & $3.71 \pm 0.24^{*}$ & $0.51 \pm 0.07^{\mathrm{a}}$ & $0.95 \pm 0.13$ *a & $0.83 \pm 0.12 \mathrm{a}, \mathrm{b}$ & $3.06 \pm 0.33 *, b$ & $1.46 \pm 0.28 \mathrm{~b}, \mathrm{c}$ & $3.47 \pm 0.61^{*, b}$ \\
\hline Week 2 & $1.17 \pm 0.09$ & $2.56 \pm 0.18^{*}$ & $0.82 \pm 0.19$ & $0.85 \pm 0.12^{a}$ & $0.96 \pm 0.17$ & $3.13 \pm 0.35 *, b$ & $1.22 \pm 0.25^{b}$ & $4.14 \pm 0.17^{*} * a, b$ \\
\hline Week 3 & $0.81 \pm 0.13$ & $2.03 \pm 0.32$ & $0.79 \pm 0.12$ & $0.50 \pm 0.07$ *a & $0.95 \pm 0.13$ & $4.58 \pm 0.18^{*, a, b}$ & $1.48 \pm 0.04^{a, b}$ & $5.46 \pm 0.27^{* a, b}$ \\
\hline Week 4 & $1.37 \pm 0.04$ & $3.42 \pm 0.11^{*}$ & $0.45 \pm 0.07^{\mathrm{a}}$ & $0.53 \pm 0.03^{\mathrm{a}}$ & $0.48 \pm 0.04 \mathrm{a}, \mathrm{b}$ & $2.58 \pm 0.20 *, b$ & $1.45 \pm 0.15^{b, c}$ & $4.19 \pm 0.23 *, b, c$ \\
\hline
\end{tabular}

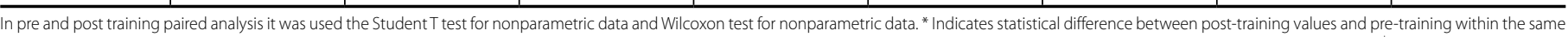

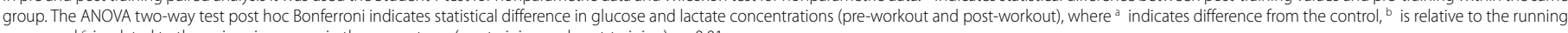
group, and ${ }^{c}$ is related to the swimming group in the same stage. (pre-training and post-training), $p<0.01$. 


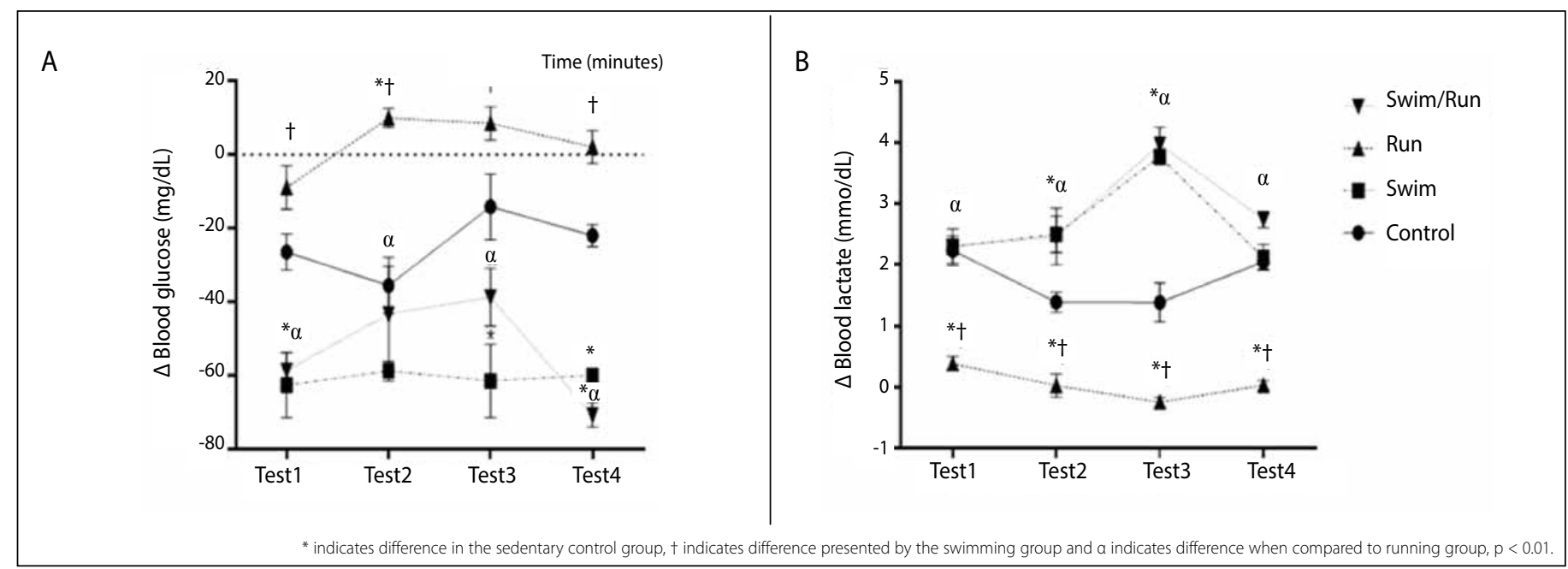

Figure 2. Changes in blood glucose (A) and lactate (B) pre and post training during the four weeks of Duathlon training. The ANOVA two-way test post hoc Bonferroni shows statistical differences between groups during the training.

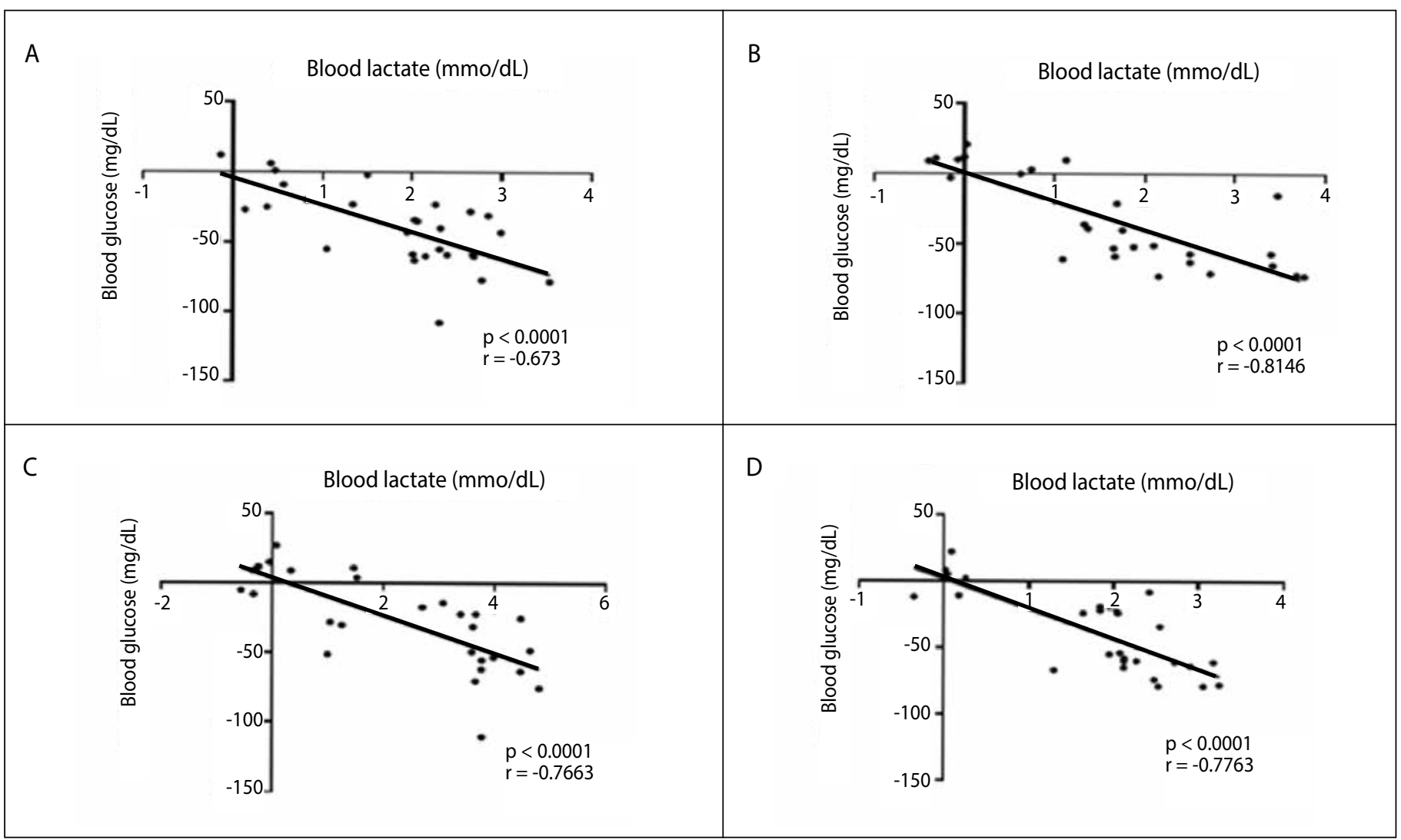

Figure 3. Correlation between the change in blood glucose and lactate during the four weeks of Duathlon training. The Spearman test shows moderate inverse correlation between the concentration of glucose and lactate in the first week of training (A) and strong correlation in the second week (B), third (C) and fourth week (D).

the muscle stores of glycogen, causing the glucose to be transported into the muscle, reducing their concentration in the bloodstream. In contrast, it was observed a steady glucose levels in both running and control group, suggesting that the training intensity was low and muscle stores of glycogen have supplied the energy demand.

Regarding the post-training blood lactate levels in swimming and swimming/running group, they showed considerably higher when compared with the running group. In a previous study, Gobatto et al. ${ }^{9}$ after submitting rats to a swimming training during 9 weeks adding $8 \%$ of their body weight, it was found that lactate concentration remained stable at $5.5 \mathrm{mmol} / \mathrm{L}$. Although the authors used a higher volume of daily training compared to the present study, it was observed that at the end of the training period, the animals adapted to the same, thus achieving a balance of lactate production / removal rate, thus stabilizing concentration of blood lactate.

In contrast, Cunha et al. ${ }^{14}$ reported that the stabilization in lactate concentration occurred at approximately $5.4 \mathrm{mmol} / \mathrm{L}$ in older rats supporting a $5 \%$ body weight load and that workloads above this would cause the lactate began to accumulate in the bloodstream. In this way, a swimming exercise lasting 30 minutes may be prescribed with a working load of not more than $5 \%$ of body weight if the goal is to stimulate aerobic pathway with stable blood lactate concentrations. 
These results differ from the findings of this study, since the swimming group trained with $8 \%$ of the body weight during 30 minutes, being observed an accumulation of serum lactate lower than that found by Cunha et al. ${ }^{14}$. However, it is important to emphasize the chronological age of the animals used in both trials, which may explain the lower lactate values even with an $8 \%$ workload of body weight. Such adaptations may be explained by a possible increase in anaerobic threshold, as Gobatto et al. ${ }^{9}$ observed during training there is a decreased production of lactate for the same training intensity or even increased of its removal.

It is worth pointing out the decrease in lactate concentration in the swimming and swimming/running group during the transition from test 3 to test 4 . It makes possible to raise a hypothesis of a training adaptation, since the rats performed their exercises, during the same amount of time and workload ( $8 \%$ of body weight), but with lower levels of serum lactate. These results corroborate in part to the study of Vieira et. al. $^{15}$, in which it was found that at the end of 5 weeks of training on the treadmill, the rats were able to run at a higher speed. However, to reach the lactate threshold it was needed a higher training intensity.
These adaptations can be explained through different aspects, such as increased hepatic, cardiac and muscular mitochondrial capacity ${ }^{15}$.

Therefore, the proposed protocol of Duathlon adapted for female rats was effective, in relation to the expectation imposed to the same at the beginning of the study, within the perspective of the association of a training of moderate intensity to high (swimming) and low intensity (running). The proposed model reduced blood glucose and increased post-training lactate concentration throughout the training, behaviors similar to those found in humans and the most relevant, it was possible to observe the stabilization in lactacidemic concentrations during the training period.

\section{ACKNOWLEDGEMENTS}

Financial support was obtained from CAPES (Higher Education Personnel Training Coordination), FUNCAP (Ceará Foundation for the Support of Scientific and Technological Development) and CNPq (National Council for Scientific and Technological Development).

All authors declare no potential conflict of interest related to this article

AUTHORS' CONTRIBUTIONS: Each author made significant individual contributions to this manuscript. FSLVF (0000-0003-3140-0085)*: Experimental execution of the study, analysis of results and writing; MBS (0000-0003-1074-9229)*: Experimental execution of the study, analysis of results and writing; JPAF (0000-0002-3225-6532)*: Experimental execution of the study; KCLS (0000-0001-9477-6229)*: Methodological supervision, analysis of results and formatting of articles; MRAC (0000-0002-5457-3109)*: Experimental execution of the study and translation of the article; FFUSJ (0000-0002-5685-4297)*: Experimental project, writing and methodological supervision; VMC (0000-0003-4839-4400)*: methodological supervision. ${ }^{*} \mathrm{ORCID}$ (Open Researcher and Contributor ID).

\section{REFERENCES}

1. Jonas S. Duathlon Training and Racing for Ordinary Mortals (R): Getting Started and Staying with it. Falcon Guides, 2012.

2. Mamus R, Santos MG. Efeitos bioquímicos da suplementação de carboidratos após uma competição simulada de Short Duathlon Terrestre. Rev Port Cien Desp. 2006;6(1):29-37.

3. Berry NT, Wideman L, Shields EW, Battaglini CL. The Effects of a Duathlon Simulation on Ventilatory Threshold and Running Economy. J Sports Sci Med. 2016;15(2):247-53.

4. Caputo F, Oliveira M, Greco C, Denadai B. Exercício aeróbio: Aspectos bioenergéticos, ajustes fisiológicos, fadiga e índices de desempenho. Rev Bras Cineantropom Desempenho Hum. 2009;1 (1):94-102.

5. Chang H, Park JY, Suk MH, Lee HJ, Kang HJ, Choi KM, et al. Comparison of lactate threshold, glucose, and insulin levels between OLETF and LETO rats after all-out exercise. J Sport Sci Med. 2009;8(3):381-7.

6. Cermak NM, Van Loon LJC. The Use of Carbohydrates During Exercise as an Ergogenic Aid. Sport Med. 2013;43(11):1139-55

7. Alghannam AF, Jedrzejewski D, Tweddle MG, Gribble H, Bilzon J, Thompson D, et al. Impact of Muscle Glycogen Availability on the Capacity for Repeated Exercise in Man. Med Sci Sports Exerc. 2016;48(1):123-31.

8. Teixeira PSA, Rego Monteiro ICC, Lima TI, Santos ACC, Ceccatto VM. Prescription of Aerobic Exercise
Training Based on the Incremental Load Test: A Model of Anaerobic Threshold for Rats. J Exerc Physiol Online. 2012;15(3):45-52.

9. Gobatto CA, Mello MA, Sibuya CY, Azevedo JR, Santos LA, Kokubun E. Maximal lactate steady state in rats submitted to swimming exercise. Comp Biochem Physiol A Mol Integr Physiol. 2001;130(1):21-7.

10. Goodwin ML. Blood glucose regulation during prolonged, submaximal, continuous exercise: a guide for clinicians. J Diabetes Sci Technol. 2010;4(3):694-705.

11. Knuiman P, Hopman MTE, Mensink M. Glycogen availability and skeletal muscle adaptations with endurance and resistance exercise. Nutr Metab (Lond). 2015;12(1):59.

12. Roberts CK, Little JP, Thyfault JP. Modification of Insulin Sensitivity and Glycemic Control by Activity and Exercise. Med Sci Sport Exerc. 2013;45(10):1868-77.

13. Ahmad NS, Ooi FK, Saat Ismail M, Mohamed M. Effects of Post-Exercise Honey Drink Ingestion on Blood Glucose and Subsequent Running Performance in the Heat. Asian J Sports Med. 2015;6(3):e24044

14. 14. Cunha RR, Carvalho CVN, Segundo PR, Moreira SR, Kokubun E, Campbell CSG,et al. Determination of the lactate threshold and maximal blood lactate steady state intensity in aged rats. Cell Biochem Funct. 2009;27(6):351-7.

15. Brito VW, Halsberghe M, Schwantes M, Perez S, Baldissera V, Prestes J, et al. Increased lactate threshold after five weeks of treadmill aerobic training in rats. Brazilian J Biol. 2014;74(2):444-9. 